\title{
Evaluation of patients who received erythrocyte transfusion in the emergency department
}

\section{Rezan Karaali $^{1}$ (D)}

1 İzmir Katip Çelebi University, Atatürk Training and Research Hospital, Emergency Department,İzmir, Turkey

\begin{abstract}
Backgrounds: Decreased RBC count and decreased $\mathrm{Hb}$ concentration in the blood is defined as anemia. Anemia can be caused by acute excessive bleeding, hemolysis or inadequate production. If the patient is symptomatic, an immediate blood transfusion is required.

Methods: A retrospective, single-center study was performed between April 2019 and April 2021 with non-traumatic, non-pregnant patients over 18 years of age, who had erythrocyte transfusion in the emergency department. For the laboratory parameters $\mathrm{Hb}$, $\mathrm{Ca}$ and $\mathrm{K}$, the initial levels from the blood analysis performed at admission to the emergency department were recorded as $\mathrm{Hb} 1$, potassium K1, and calcium Ca1, and the blood levels after the transfusion as $\mathrm{Hb} 2, \mathrm{~K} 2$, and Ca2. Mortality of patients was recorded.

Results: A total of 458 patients were included in the study. $44.3 \%$ of patients were male. The mean age was $66.33 \pm 17.51 /$ year. Mortality developed in $6.55 \%$. There was a statistically significant difference in laboratory values between non-surviving and surviving patients. The mortality rate increased in patients with $\mathrm{Hb} 1$ values below $5.05 \mathrm{~g} / \mathrm{dl}$ and $\mathrm{Hb} 2$ values below $7.75 \mathrm{~g} / \mathrm{dl}$, and patients with Ca1-2 values below $6.85 \mathrm{mg} / \mathrm{dl}$. It was determined that this increase in mortality rate was 3 to 6 times on average.

Conclusions: Our findings reveal that the transfusion procedures in our clinic are in accordance with the new transfusion guidelines. It is important to use blood and blood products, the only source of which is human, for the right indication, at the right time, and in the right amounts.
\end{abstract}

Keywords: Anemia, Emergency, Erythrocyte Transfusion. 


\section{INTRODUCTION}

Approximately $80 \%$ of the cells in our body are red blood cells (RBC). Hemoglobin $(\mathrm{Hb})$ is the main component of RBC content. Decreased RBC count and decreased $\mathrm{Hb}$ concentration in the blood is defined as anemia (1). Anemia can be caused by acute excessive bleeding, hemolysis or inadequate production of erythrocytes. The World Health Organization defines anemia as an $\mathrm{Hb}$ level of $\leq 13 \mathrm{~g} / \mathrm{dl}$ in men and $\leq 12 \mathrm{~g} /$ $\mathrm{dl}$ in women $(2,3)$. In cases of acute anemia, traumatic or non-traumatic hemorrhage, an $\mathrm{Hb}$ level of $<7 \mathrm{~g} / \mathrm{dl}$ in critically ill patients, $<9 \mathrm{~g} / \mathrm{dl}$ in sepsis patients, septic shock, cardiac ischemia, acute or chronic blood loss, and if the patient is symptomatic, an immediate blood transfusion is required $(2,4,5)$.

In the United States, 24 million blood or blood products are transfused each year (6). While blood transfusion can be life-saving, it is also associated with life-threatening risks and complications $(5,7,8)$. Therefore, blood transfusion is a treatment method that should be used at the right time, for the right indication.

The emergency department of our hospital is a tertiarycare emergency department. Thus, a large number of patients with acute bleeding and/or critical condition present to our department. Treatment of these patients is initiated at our emergency department. One of these treatments is blood transfusion.

In the present study, we aimed to assess the patients who were administered erythrocyte suspension (ES) at our emergency department.

\section{MATERIALS AND METHODS}

\section{Study design}

This study was a single-center retrospective study. The study was initiated after the approval by the ethics committee of İzmir Katip Çelebi University (Decision date: 24.06.2021, and No: 290).

Patients presenting to our emergency department between April 30, 2019 and April 30, 2021, who had an $\mathrm{Hb}$ level of $\leq 9 \mathrm{~g} / \mathrm{dl}$ and had anemia-related symptoms (shortness of breath, palpitation, dizziness, weakness, chest pain) and signs (tachycardia, hypotension, hypoxia, hypothermia, pallor, signs of ischemia on electrocardiography (ECG)), and received erythrocyte transfusion in the emergency department, were screened using the hospital automation system. Patients over the age of 18 with sufficient data in their files who had undergone erythrocyte transfusion in the emergency department were included in the study.

Patients with trauma and pregnants were excluded from the study.

\section{Study protocol}

Patients' age, gender, blood type, repeated transfusions, number of ES units administered at the emergency department, discharge/hospitalization after transfusion at the emergency department, laboratory results, and levels of $\mathrm{Hb}$, calcium $(\mathrm{Ca})$, potassium $(\mathrm{K})$, mean corpuscular volume $(\mathrm{MCV})$, mean corpuscular hemoglobin $(\mathrm{MCH})$, mean corpuscular hemoglobin concentration (MCHC), red blood cell distribution width (RDW) were recorded from patient files.

For the laboratory parameters $\mathrm{Hb}, \mathrm{Ca}$ and $\mathrm{K}$, the initial levels from the blood analysis performed at admission to the emergency department were recorded as $\mathrm{Hb} 1$, potassium K1, and Ca1, and the blood levels after the transfusion were recorded as $\mathrm{Hb} 2, \mathrm{~K} 2$, and $\mathrm{Ca} 2$. 30-day mortality was recorded.

\section{Statistical method:}

The study data were assessed using IBM SPSS Statistics Version 20. The use of parametric or nonparametric tests was decided by analyzing the normality of the quantitative data using the One-Sample Kolmogorov-Smirnov test. Frequency and percentage distribution were calculated for descriptive statistics, and mean, standard deviation, minimum and maximum values for continuous variables.

Statistical analyses and interpretations of categorical variables were performed using Pearson's Chi-Square and Fisher's Exact tests. Categorical data were expressed as $\mathrm{n}$ (number) and percentage (\%). The data were analyzed at the $95 \%$ confidence level, according to the probability reference value of 0.05 .

The effect of laboratory values in determining the final status of the patients was examined using the ROC Analysis, and the cut-off values for the variables with statistical difference were calculated. 


\section{RESULTS}

A total of 458 of 551 patients who met the study criteria and had sufficient data in their files were included in the study. Male patients accounted for $44.30 \%$ of the study participants. The mean age was $66.33 \pm 17.51 /$ year. Demographic characteristics of the study patients and distribution of the study parameters are presented in Table 1.

Table1. Demographic characteristics of patients and distribution of parameters evaluated in the study

\begin{tabular}{|c|c|c|c|}
\hline Category & Variables & (n) & $\%$ \\
\hline \multirow[t]{2}{*}{ Gender } & Male & 203 & $44.30 \%$ \\
\hline & Female & 255 & $55.70 \%$ \\
\hline Age $($ mean \pm SD) & $66,33 \pm 17,51$ & 458 & \\
\hline \multirow[t]{8}{*}{ Blood type } & $0-$ & 14 & $3.10 \%$ \\
\hline & $0+$ & 145 & $31.60 \%$ \\
\hline & A- & 20 & $4.40 \%$ \\
\hline & $\mathrm{A}+$ & 156 & $34.00 \%$ \\
\hline & AB- & 4 & $0.90 \%$ \\
\hline & $\mathrm{AB}+$ & 27 & $5.90 \%$ \\
\hline & B- & 5 & $1.10 \%$ \\
\hline & $\mathrm{B}+$ & 87 & $19.00 \%$ \\
\hline Repetitive & Yes & 152 & $33.18 \%$ \\
\hline Transfusion & No & 306 & $66.81 \%$ \\
\hline \multirow{4}{*}{$\begin{array}{l}\text { Amount of transfusion } \\
\text { (units) }\end{array}$} & 1 & 60 & $13.10 \%$ \\
\hline & 2 & 265 & $57.86 \%$ \\
\hline & 3 & 116 & $25.33 \%$ \\
\hline & 4 & 17 & $3.71 \%$ \\
\hline \multirow[t]{3}{*}{ Hospitalization status } & Discharged from ED & 292 & $63.80 \%$ \\
\hline & Hospitalization on ward & 142 & $31.00 \%$ \\
\hline & Hospitalization on ICU & 24 & $5.20 \%$ \\
\hline \multirow[t]{2}{*}{ Cause of anemia } & Hemorrhagic & 128 & $27.90 \%$ \\
\hline & Nonhemorrhagic & 330 & $72 ., 10 \%$ \\
\hline \multirow[t]{2}{*}{ Mortality } & Yes & 30 & $6.55 \%$ \\
\hline & No & 428 & $93.45 \%$ \\
\hline
\end{tabular}

Mortality developed in $6.55 \%$ of our study patients. When the mortality was evaluated, the comparison of non-surviving and surviving patients revealed a statistically significant difference in the number of ES units administered to the patient and the hospitalization of the patient (Table 2). 
Table 2. Evaluation of the values obtained in the study in terms of mortality

\begin{tabular}{|c|c|c|c|c|c|c|}
\hline \multicolumn{7}{|l|}{ Mortality } \\
\hline \multirow[b]{2}{*}{ Category } & \multirow[b]{2}{*}{ Variables } & \multicolumn{2}{|l|}{ Exitus } & \multicolumn{2}{|l|}{ Live } & \multirow[b]{2}{*}{$\mathrm{p}$} \\
\hline & & Count & Row n \% & Count & Row n \% & \\
\hline \multirow[b]{2}{*}{ Gender } & Male & 12 & 5.90 & 191 & 94.10 & \multirow[b]{2}{*}{0.622} \\
\hline & Female & 18 & 7.10 & 237 & 92.90 & \\
\hline \multicolumn{2}{|l|}{ Age $($ mean $\pm S D)$} & 30 & $70.90 \pm 15.15$ & 428 & $66.01 \pm 17.63$ & 0.87 \\
\hline \multirow{8}{*}{ Blood type } & $0-$ & 0 & 0.00 & 14 & 100.00 & \multirow[b]{8}{*}{0.415} \\
\hline & $0+$ & 6 & 4.10 & 139 & 95.90 & \\
\hline & A- & 0 & 0.00 & 20 & 100.00 & \\
\hline & $\mathrm{A}+$ & 15 & 9.60 & 141 & 90.40 & \\
\hline & $\mathrm{AB}-$ & 0 & 0.00 & 4 & 100.00 & \\
\hline & $\mathrm{AB}+$ & 2 & 7.40 & 25 & 92.60 & \\
\hline & B- & 0 & 0.00 & 5 & 100.00 & \\
\hline & $\mathrm{B}+$ & 7 & 8.00 & 80 & 92.00 & \\
\hline \multirow{2}{*}{ Repetitive transfusion } & Yes & 8 & 5.30 & 144 & 94.70 & \multirow[b]{2}{*}{0.442} \\
\hline & No & 21 & 6.90 & 285 & 93.10 & \\
\hline \multirow{4}{*}{$\begin{array}{l}\text { Amount of transfusion/ } \\
\text { units }\end{array}$} & 1 & 1 & 1.70 & 59 & 98.30 & \multirow[b]{4}{*}{0.021} \\
\hline & 2 & 13 & 4.90 & 252 & 95.10 & \\
\hline & 3 & 13 & 11.20 & 103 & 88.80 & \\
\hline & 4 & 3 & 18.80 & 14 & 81.30 & \\
\hline \multirow{3}{*}{ Hospitalization status } & $\begin{array}{l}\text { Discharged from } \\
\text { ED }\end{array}$ & 9 & 3.80 & 283 & 96.91 & \multirow[b]{3}{*}{0} \\
\hline & $\begin{array}{l}\text { Hospitalization } \\
\text { on ward }\end{array}$ & 11 & 7.80 & 131 & 92.30 & \\
\hline & $\begin{array}{l}\text { Hospitalization } \\
\text { in ICU }\end{array}$ & 10 & 41.70 & 14 & 58.30 & \\
\hline \multirow[b]{2}{*}{ Cause of anemia } & Nonhemorrhagic & 21 & 21 & 309 & 79 & \multirow[b]{2}{*}{0.648} \\
\hline & Hemorrhagic & 9 & $7,00 \%$ & 119 & $93,00 \%$ & \\
\hline
\end{tabular}

ED: Emergency department, ICU: Intensive care unit.

There was a statistically significant difference between $\mathrm{Hb} 1$, $\mathrm{Hb} 2, \mathrm{Ca} 1$, and $\mathrm{Ca} 2$ values of non-surviving and surviving patients (Table 3). The logistic regression analysis for the effects of these parameters on mortality revealed that the cut-off value for $\mathrm{Hb} 1$ and $\mathrm{Hb} 2$ was moderately effective, the cut-off value for Ca1 was fairly effective, and the cut-off value for Ca2 was moderately effective (Table 4). 
Table 3. Mean laboratory values of patients and relationship with mortality

\begin{tabular}{|c|c|c|c|c|}
\hline & Exitus $(n=30)$ & Live(n=398) & Total $(N=428)$ & $\mathrm{p}$ \\
\hline $\begin{array}{l}\text { Laboratory } \\
\text { parameters }\end{array}$ & Mean \pm SD & Mean \pm SD & $\begin{array}{l}\text { Mean } \pm \text { SD } \\
\text { Min-max }\end{array}$ & \\
\hline $\mathrm{Hb} 1 \mathrm{~g} / \mathrm{dl}$ & \begin{tabular}{|l}
$5.78 \pm 1.33$ \\
$3.30-8.70$
\end{tabular} & $\begin{array}{l}6.47 \pm 1.07 \\
3.00-8.90\end{array}$ & $\begin{array}{l}6.43 \pm 1.1 \\
3.00-8.90\end{array}$ & 0.001 \\
\hline $\mathrm{Hb} 2 \mathrm{~g} / \mathrm{dl}$ & \begin{tabular}{|l|}
$8.76 \pm 1.14$ \\
$6.40-11.50$
\end{tabular} & $\begin{array}{l}9.31 \pm 1.15 \\
6.80-14.80\end{array}$ & $\begin{array}{l}9.28 \pm 1.15 \\
6.40-14.80\end{array}$ & 0.014 \\
\hline $\mathrm{Ca} 1 \mathrm{mg} / \mathrm{dl}$ & $\begin{array}{l}7.78 \pm 0.70 \\
6.10-9.60 \\
\end{array}$ & $\begin{array}{l}8.17 \pm 0.79 \\
3.20-12.60\end{array}$ & $\begin{array}{l}8.15 \pm 0.79 \\
3.20-12.60\end{array}$ & 0.002 \\
\hline $\mathrm{Ca} 2 \mathrm{mg} / \mathrm{dl}$ & \begin{tabular}{|l|}
$7.49 \pm 0.77$ \\
$6.30-9.70$
\end{tabular} & $\begin{array}{l}8.02 \pm 0.68 \\
5.90-12.30\end{array}$ & $\begin{array}{l}7.99 \pm 0.70 \\
5.90-12.30\end{array}$ & 0.000 \\
\hline $\mathrm{K} 1 \mathrm{mmol} / \mathrm{L}$ & $\begin{array}{l}4.68 \pm 1.05 \\
2.90-7.60\end{array}$ & $\begin{array}{l}4.38 \pm 0.70 \\
2.20-8.40\end{array}$ & $\begin{array}{l}4.40 \pm 0.73 \\
2.20-8.40\end{array}$ & 0.115 \\
\hline $\mathrm{K} 2 \mathrm{mmol} / \mathrm{L}$ & \begin{tabular}{|l|}
$4.35 \pm 0.93$ \\
$2-6.20$
\end{tabular} & $\begin{array}{l}4.38 \pm 0.54 \\
2.80-5.90\end{array}$ & $\begin{array}{l}4.38 \pm 0.57 \\
2.00-6.20\end{array}$ & 0.902 \\
\hline $\mathrm{MCV} f \mathrm{fl}$ & $\begin{array}{l}82.16 \pm 11.60 \\
57.00-105.90\end{array}$ & \begin{tabular}{|l|}
$80.8 \pm 15.63$ \\
$50.60-141.90$
\end{tabular} & $\begin{array}{l}80.89 \pm 15.39 \\
50.60-141.90\end{array}$ & 0.315 \\
\hline $\mathrm{MCH}$ pg & $25.28 \pm 5.23$ & $24.82 \pm 6.48$ & $\begin{array}{l}24.85 \pm 6.4 \\
13.40-47.60\end{array}$ & 0.524 \\
\hline $\mathrm{MCHC}$ g/dl & $\begin{array}{l}30.55 \pm 2.91 \\
23.20-36.90\end{array}$ & $\begin{array}{l}30.30 \pm 2.70 \\
19.40-36.90\end{array}$ & $\begin{array}{l}30.31 \pm 2.71 \\
19.40-36.90\end{array}$ & 0.532 \\
\hline RDW fl & $18.93 \pm 3.03$ & $18.56 \pm 3.14$ & $\begin{array}{l}18.58 \pm 3.14 \\
12.10-32.40\end{array}$ & 0.540 \\
\hline
\end{tabular}

Hb: Hemoglobin, Ca: Calcium, K: Potassium, MCV: Mean Corpuscular Volume, MCH: Mean Corpuscular Hemoglobin, MCHC: Mean Corpuscular Hemoglobin Concentration, RDW: Red Blood Cell Distribution Width.

Table 4. ROC analysis of laboratory values associated with mortality

\begin{tabular}{|c|c|c|c|c|c|c|c|}
\hline \multirow{2}{*}{ Risk factor } & \multicolumn{3}{|l|}{ AUC (\%95) } & \multirow{2}{*}{ Cut-Off } & \multirow{2}{*}{$\mathbf{P}$} & \multirow{2}{*}{ Sensitivity (\%) } & \multirow{2}{*}{ Specificity $(\%$} \\
\hline & AUC $(\% 95)$ & Lower Bound & Upper Bound & & & & \\
\hline $\mathrm{Ca} 1 \mathrm{mg} / \mathrm{dl}$ & 0.669 & 0.577 & 0.766 & 6.85 & 0.00 & 13 & 96 \\
\hline $\mathrm{Ca} 2 \mathrm{mg} / \mathrm{dl}$ & 0.725 & 0.625 & 0.827 & 6.85 & 0.00 & 23 & 97 \\
\hline $\mathrm{Hb} 1 \mathrm{~g} / \mathrm{dl}$ & 0.681 & 0.575 & 0.787 & 5.05 & 0.00 & 33 & 89 \\
\hline $\mathrm{Hb} 2 \mathrm{~g} / \mathrm{dl}$ & 0.635 & 0.624 & 0.826 & 7.75 & 0.01 & 23 & 95 \\
\hline \multicolumn{8}{|c|}{$\begin{array}{l}\text { The test result variable(s): hb1, hb2, potasyum1, potasyum2, kalsiyum1, kalsiyum2, mcv, mch, mchc, rdw has at least } \\
\text { one tie between the positive actual state group and the negative actual state group. Statistics may be biased. }\end{array}$} \\
\hline \multicolumn{8}{|c|}{ a. Under the nonparametric assumption } \\
\hline \multicolumn{8}{|c|}{ b. Null hypothesis: true area $=0.5$} \\
\hline
\end{tabular}

Ca: Calcium, Hb: Hemoglobin. 
In Table 5, cut-off values of $\mathrm{Hb}$ and $\mathrm{Ca}$, which were associated with mortality before and after transfusion, and mortality rates of the patients were evaluated. It predicted an $18 \%$ probability of mortality when the $\mathrm{Hb} 1$ cut-off value was below $5.05 \mathrm{~g} / \mathrm{dl}$. For $\mathrm{Hb} 1$ above this value, the probability of mortality was $5 \%$. It predicted a $32 \%$ probability of mortality when the Ca2 cut-off value was below $6.85 \mathrm{mg} / \mathrm{dl}$. For Ca2 above this value, the probability of mortality was found to be $5 \%$ (Table 5) (Figure 1).

Table 5. The mortality rates of the patients according to the cutoff values of hemoglobin and calcium, which were determined to be associated with mortality

\begin{tabular}{|c|c|c|c|c|c|c|c|c|c|c|c|c|c|c|c|c|}
\hline & \multicolumn{4}{|c|}{ Hemoglobin1 g/dl } & \multicolumn{4}{|c|}{ Hemoglobin2 g/dl } & \multicolumn{4}{|c|}{ Calsiyum1 mg/dl } & \multicolumn{4}{|c|}{ Calsiyum2 mg/dl } \\
\hline \multirow[t]{2}{*}{ Cut-off Value } & \multicolumn{4}{|c|}{5.05} & \multicolumn{4}{|c|}{7.75} & \multicolumn{4}{|c|}{6.85} & \multicolumn{4}{|c|}{6.85} \\
\hline & $<$ & $\%$ & $>$ & $\%$ & $<$ & $\%$ & $>$ & $\%$ & $<$ & $\%$ & $>$ & $\%$ & $<$ & $\%$ & $>$ & $\%$ \\
\hline Exitus & 10 & 18 & 20 & 5 & 7 & 24 & 23 & 5 & 4 & 17 & 26 & 6 & 7 & 32 & 23 & 5 \\
\hline Live & 47 & 82 & 381 & 95 & 22 & 76 & 406 & 95 & 19 & 83 & 409 & 94 & 15 & 68 & 413 & 95 \\
\hline Total & 57 & 100 & 401 & 100 & 29 & 100 & 429 & 100 & 23 & 100 & 435 & 100 & 22 & 100 & 436 & 100 \\
\hline
\end{tabular}

Figure 1. ROC analysis of laboratory values

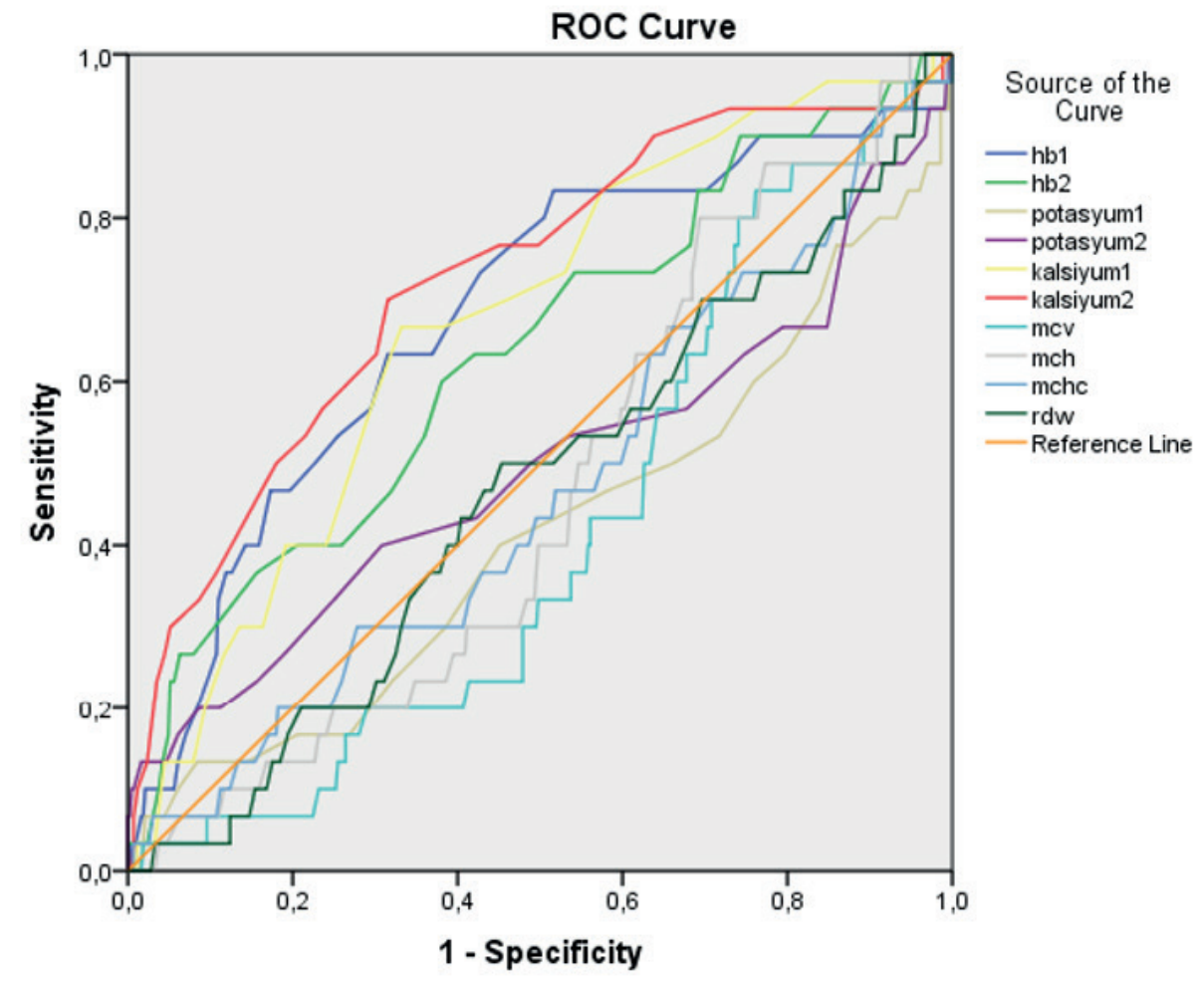

Diagonal segments are produced by ties. 


\section{DISCUSSION}

Blood transfusion has been widely used since the early $20^{\text {th }}$ century to treat anemia and acute blood loss $(4,9)$. Patient assessment and transfusion decision are of critical importance in emergency departments, which is the first location of admission of these patients.

In our study, female patients accounted for $55.7 \%$ of the patient group. Worldwide, women are more susceptible to anemia. Poor nutritional conditions, increased menstrual bleeding, abnormal uterine bleeding, pregnancy and breastfeeding are the factors that increase the susceptibility to anemia in women (10-12). Therefore, anemia is more prevalent in women. The mean age of the patients included in the study was $66 \pm 17.51$ / years. Patients who need urgent ES transfusion are relatively elderly patients. Because young patients can tolerate anemia better, chronic and comorbid diseases are less common in young patients, and etiological factors leading to anemia can be treated more effectively in young patients (13).

Considering the etiological factors that required transfusion in our study, the rate of patients who needed transfusion due to acute bleeding was $27.9 \%$. Anemia, which occurs secondary to the existing diseases in the majority of the patients, becomes symptomatic, and therefore transfusion is needed, which can also be considered an effect of advanced age. The guidelines on the approach to anemia occurring other than acute blood loss recommend that patients without any indication for hospitalization, should be investigated in outpatient clinics, the etiology causing anemia should be determined and the treatment should be continued $(2,5,14)$. In our study, $63.8 \%$ of the study patients were discharged from the emergency department after transfusion to refer to the outpatient clinic. From this point of view, it can be said that the transfusion procedures carried out in our emergency department comply with the guidelines. Transfusion administration to the patients at the emergency department provided symptomatic treatment of the patients, and thereby the patients were discharged from the emergency department without the need for hospitalization. Thus, both the treatments of the patients were provided and the rate of hospitalization was reduced.

Consensus and guidelines have been established to provide global standardization for blood transfusion.
According to these guidelines, the current transfusion approach is restrictive approaches. According to the restrictive transfusion approach, the threshold for transfusion is $\mathrm{Hb}<6 \mathrm{~g} / \mathrm{dL}$ for healthy and stable patients who can tolerate low RBC levels. Although different levels have been suggested for specific conditions such as acute coronary syndrome, cardiac surgery, orthopedic surgery, and oncology patients, it is recommended to initiate transfusion after the mean $\mathrm{Hb}$ level is $\leq 7-8 \mathrm{~g} / \mathrm{dl}$ and the clinical status of the patients is assessed $(2,4-6,14)$. In our study, the $\mathrm{Hb}$ level of the patients initiated on transfusion was $6.43 \pm 1.1 \mathrm{~g} / \mathrm{dl}$. Thus, it is observed that the Hb levels during transfusion decision in the present study are consistent with those recommended by the guidelines. It can be said that in our emergency department, the need for transfusion was determined accurately and the patients received adequate and proper transfusions.

The mortality rate of our patients was found to be $6.55 \%$. When the parameters affecting mortality was evaluated, it was found that $\mathrm{Hb}$ levels were associated with mortality before and after transfusion. Accordingly, the mortality rate was $18 \%$ in patients with an $\mathrm{Hb}$ level of $<5.05 \mathrm{~g} / \mathrm{dl}$ before transfusion, while it was reduced to $5 \%$ in patients with $\mathrm{Hb}$ levels above this value. In their review evaluating studies on Jehovah's Witnesses, Viele et al. reported that the $\mathrm{Hb}$ level of non-surviving patients was $<5 \mathrm{~g} / \mathrm{dl}$ (15). In the most recent guidelines, the recommended mean threshold for initiation of transfusion is $7-8 \mathrm{~g} / \mathrm{dl}(2,5,14)$. According to our results, initiation of transfusion before the $\mathrm{Hb}$ cut-off value drops down to $<5 \mathrm{~g} / \mathrm{dl}$ may reduce mortality in patients with acute blood loss. For patients with chronic anemia, it should be considered that patients with an $\mathrm{Hb}$ cut-off value $<5 \mathrm{~g} / \mathrm{dl}$ are critically ill.

When the post-transfusion $\mathrm{Hb}$ levels were evaluated in our study, the mortality rate was $24 \%$ in patients with an $\mathrm{Hb}$ level of $<7.75 \mathrm{~g} / \mathrm{dl}$, while the mortality rate decreased to $5 \%$ in patients with an $\mathrm{Hb}$ level of $\geq 7.75 \mathrm{~g} / \mathrm{dl}$. In the recent guidelines, restrictive transfusion recommendations have emphasized that the patient's blood levels and clinical data should be checked after each unit of transfusion and the transfusion should be maintained accordingly. However, a value to terminate the transfusion has not been determined $(2,5,16)$. Considering this aspect, we believe that the cut-off value found in our study is important. The reduced mortality by keeping a target $\mathrm{Hb}$ value of 
$\geq 7.75 \mathrm{~g} / \mathrm{dl}$ after transfusion will guide future studies and guidelines. The amount of blood required to reach these critical values, that is, the number of units given to the patient, also plays an important role in the survival of the patient. In our study, it was found that as the amount of blood (unit) given to the patient increases, the mortality also increases. We believe that the volume load due to the blood component administered to the patient and the patient instability due to the condition requiring excessive transfusion contribute to mortality. Therefore, it is necessary to avoid giving too much blood to patients in accordance with restrictive transfusion protocols as recommended in the guidelines. This is supported by our results. The patient's need for transfusion should be determined early and transfusion should be performed gradually.

The level of $\mathrm{Ca}$ is another parameter that was found to be associated with mortality. As is known, Ca is involved in cardiomyocytes, coagulation and contraction of skeletal muscle. RBC are preserved in solutions containing citrate. Citrate binds to $\mathrm{Ca}$ in the blood to form a dispersible complex, but this complex is weakly ionized. Thus, most of the Ca bound to citrate becomes biologically inactive. Because it binds to citrate, the blood level of Ca decreases in patients receiving transfusion $(2,8)$. Ca levels should be evaluated in patients during and after transfusion, and replacement should be administered, if necessary $(2,17)$. In their study, Bıçakçı et al. found that Ca levels of $<7.9 \pm 1.13 \mathrm{mg} / \mathrm{dl}$ were associated with mortality in patients who received ES transfusion, although patients with hypocalcemia received replacement (17). In addition, in our study, the patient's pre-transfusion calcium level was also found to be associated with mortality. It was determined that mortality increased 3 to 6 times in patients with calcium levels below $6.85 \mathrm{mg} / \mathrm{dl}$ before and after transfusion. This indicates that it is important to evaluate Ca levels before transfusion and to administer Ca replacement to patients with hypocalcemia.

In conclusion, in acute bleeding and symptomatic anemia, the decision of transfusion is made in the emergency department and it is important to use blood and blood products, the only source of which is human, for the right indication, at the right time, and in the right amounts. It should be kept in mind that female patients are more susceptible to anemia and may need transfusion. In our study, $63.8 \%$ of the study patients were discharged from the emergency department after transfusion and the mortality rate was $6.55 \%$ in patients who received blood transfusion. We observed that mortality increased in cases where $\mathrm{Hb}$ was $<5.05 \mathrm{mg} / \mathrm{dl}$ before transfusion and $\mathrm{Hb}<7.75 \mathrm{~g} / \mathrm{dl}$ after transfusion. We found that mortality increased when the Ca level was $<6.85$. The results of our study are guiding in decision making and transfusion management in emergency departments and will provide an insight for prospective and multicenter studies to restructure current transfusion practices in the emergency departments.

\section{Declarations}

The authors received no financial support for the research and/or authorship of this article. There is no conflict of interest.

This study was approved by the clinical research ethics committee of the İzmir Katip Çelebi University (Date: 26.06.2021 number: 0290) and written consent was obtained from all patients participating in the study.

\section{REFERENCES}

1. Hare GMT, Cazorla-Bak MP, Ku SFM, Chin K, Mistry N, Sklar MC et al. When to transfuse your acute care patient? A narrative review of the risk of anemia and red blood cell transfusion based on clinical trial outcomes. Can J Anaesth. 2020;67:1576-94.

2. American Red Cross. A Compendium of Transfusion Practice Guidelines Edition 4.0. 2021. Available at: https://www. redcrossblood.org/content/dam/redcrossblood/hospital-pagedocuments/334401_compendium_v04jan2021_bookmarkedworking_ rwv01.pdf Accessed September 20, 2021

3. World Health Organization. Haemoglobin concentrations for the diagnosis of anaemia and assessment of severity. 2011. Available at: https: / / www.who.int/vmnis/indicators/haemoglobin.pdf Accessed May 20, 2020.

4. Yaddanapudi S, Yaddanapudi L. Indications for blood and blood product transfusion. Indian J Anaesth. 2014;58:538-42.

5. Carson JL, Guyatt G, Heddle NM, Grossman BJ, Cohn CS, Fung MK et al. Clinical Practice Guidelines From the AABB: Red Blood Cell Transfusion Thresholds and Storage. JAMA. 2016;316:2025-35.

6. Goodnough LT, Levy JH, Murphy MF. Concepts of blood transfusion in adults. Lancet. 2013:381:1845-54.

7. Serious Hazards of Transfusion (SHOT) Working Expert Group. Annual SHOT Report. 2018. Available at: https: / / www.shotuk.org/ wp-content/uploads/myimages/SHOT-Report-2018_Web_Version-1. pdf Accessed May 21, 2020. 
8. Maxwell MJ, Wilson MJA. Complications of blood transfusion. Continuing Education in Anaesthesia Critical Care \& Pain 2006:6;225-9.

9. Franchini M, Marano G, Mengoli C, Pupella S, Vaglio S, Muñoz M et al. Red blood cell transfusion policy: a critical literature review. Blood Transfus. 2017;15:307-17.

10. Dugdale M. Anemia. Obstet Gynecol Clin North Am. 2001;28:363-81.

11. Vásquez-Velásquez C, Gonzales GF. Situación mundial de la anemia en gestantes [Global situation of anemia in pregnant women]. Nutr Hosp. 2019;36:996-7.

12. Teshale AB, Tesema GA, Worku MG, Yeshaw Y, Tessema ZT. Anemia and its associated factors among women of reproductive age in eastern Africa: A multilevel mixed-effects generalized linear model. PLoS One. 2020;15:e0238957.

13. Boureau AS, de Decker L. Blood transfusion in older patients. Transfus Clin Biol. 2019;26(3):160-163.

14. Mueller MM, Van Remoortel H, Meybohm P, Aranko K, Aubron C, Burger R, et al. Patient Blood Management: Recommendations From the 2018 Frankfurt Consensus Conference. JAMA. 2019;321(10):983997.

15. Levent A, Köse Ö, Linke P, Gehrke T, Çıtak M. Does tourniquet use decrease blood loss following primary total knee arthroplasty in Jehovah's Witness patients? Jt Dis Relat Surg. 2020;31(3):419-425.

16. Wang JK, Klein HG. Red blood cell transfusion in the treatment and management of anaemia: the search for the elusive transfusion trigger. Vox Sang. 2010;98:2-11.

17. Bıçakçı Z, Olcay L. Citrate metabolism and its complications in non-massive blood transfusions: association with decompensated metabolic alkalosis+respiratory acidosis and serum electrolyte levels. Transfus Apher Sci. 2014;50:418-26. 